\title{
Lessons from the Edge of the Stage: The Tintamarre Project
}

\author{
Alex Fancy \\ Mount Allison University \\ Canada
}

\begin{abstract}
Alex Fancy is the founder and director of the bilingual campus theatre company Tintamarre (created in 1982 after a decade of experimentation). On April 2, 2013, assisted by three students from the Tintamarre project (Rosalind Crump, Bernard Soubry, and David White), Professor Fancy gave a keynote address at the Second International Conference on Second-language Pedagogy at the University of Guelph. Recognised for his contributions to the promotion of bilingualism and biculturalism by the province of New Brunswick (Lieutenant-Governor's Dialogue Award) and to university teaching (3M National Teaching Fellowship), Professor Fancy offers insight into pedagogy, shared responsibility, dialogue, openness, risk-taking and language learning.
\end{abstract}

Good morning. Bonjour. Thank you very much for inviting us to share Tintamarre, an idea that became a project spanning a career, engaging many students since I first had the courage-or the audacity-to stage a play for, and with, a group of restless students who were expected to learn a second language under less than optimal conditions. That was in 1968 !

First, a metaphor for teaching and learning: as teachers, we are actors whose goal is to become spectators, while students are spectators whose goal is—or should be-to become actors.

And as a teacher-director, I have spent most of my career at the edge of the stage, and have played a role that, to borrow-and use very loosely —a term from Augusto Boal, could be called "spect-actor." Boal might have used the term "oppressed" to describe the class that started all of this!

Here at the edge of the stage, another metaphor comes to mind: teaching and learning are a dance, where leadership is passed back and forth, many times during a class or a rehearsal, back and forth between 'teacher' and 'learner,' between spect-actor and spect-actor. In this metaphor, everyone is a teacher, and everyone is a learner, leading and following, changing roles from one minute to the next, all carried on by "entrainment" (entraînement), Edward Hall's term for neurological engagement.

For several decades, I have been a teacher, and a learner, 'spect-actor' if you will, engaged in a process of comanagement, constantly rediscovering, as Malcolm Gladwell argues in Outliers, that teamwork is at least as important as talent.

For that reason, I am pleased not to have come alone to share lessons from the edge of the stage: Rosalind, David and Bernard are with me this morning. All three are members of the current team, and have helped to create, and are performing in Album, our 2012-2013 collaborative, bilingual—French and English with a bit of German—comedy.

All three are students first, actors second, and they, like generations before them, are teaching me important lessons. Now, a sentence of introduction for each of my co-spect-actors. (Rosalind introduced David, who introduced Bernard, who introduced Rosalind).

A huge Merci! to the conference organizers for their spontaneous and generous response to my suggestion that, given the collaborative nature of our work, students might come to Guelph to help me share the message from Tintamarre, our bilingual campus theatre community. Later this morning, they will offer a workshop that builds on some of the ideas I will share with you during this session. We are so sorry we can only be with you for part of today. Album opens next Wednesday! At this time tomorrow, David and I will be in our little studio theatre, helping to set light cues; tomorrow afternoon we will all be engaged in our first of three technical rehearsals before Wednesday.

David is assistant director of Album, for academic credit, and, on his own initiative, has created and animated a weekly campus radio program where he interviews actors and others to update the community on the process, and progress, around Album.

Rosalind is co-hosting David's Tintamatin ${ }^{1}$ (David's term) and, in the fall semester, completed for academic credit a project aimed at identifying the specificity of the Tintamarre process as a strategy for community-building. 
Bernard has created our website, also a blog on the subject of our school tours, and has made the weekly Tintamatin available as podcasts, ${ }^{2}$ and at the iTunes virtual store.

Of course, all three also play roles in Album, our comedy about a very large, 'post-nuclear' family in an age when we are experiencing a short-term memory crisis. They, like the twenty-seven other members of our cast, play roles because they volunteered at the beginning of the year to participate in the Tintamarre community and process, and they receive no academic credit for their work. However, the informal benefits they receive, on the linguistic, human and social levels, are another story!

The other cast members are also here in spirit, and they have written you postcards, some of which will be read by the three who are here this morning.

Next, a bit of story telling before I identify some of the lessons I have learned, and continue to learn, at the edge of the stage. Some consider story telling a privilege of the old, while others consider it an... affliction.

Imagine a very poor, naïve twenty-year-old, who has grown up on a farm in Maritime Canada. Imagine him arriving, thanks to a scholarship, in Paris during the final year of the Algerian War, when tensions between the OAS (secret army) and the FLN (National Liberation Front) are playing out in the streets of the city, with many demonstrations, pervasive police presence, and the occasional bombing.

Imagine his wonderment when he enters the cacophony of the courtyard of the Sorbonne, where people are hawking flyers that portray the virtues of Marxism, Leninism, Maoism and so on. This is pretty heady stuff!

It's a lonely, cold winter-with no social networking of the $21^{\text {st }}$ century type-in the midst of the Parisian crowd, but two poles of the young student's existence are:

(i) manifestations: demonstrations where actants-and not acteurs, to use the term favoured by Patrice Pavis-are playing out their engagement with political life. The Fifth Republic has got underway, de Gaulle is in power, and 1968the so-called Second French Revolution—is still a few years away, but tensions are building;

and (ii) theatre. He's not a theatre student, and has no idea that theatre will ever play an important role in his life, but it is a very cold winter, not just harsh on the political front, and he's living in Montparnasse, close to some théâtres de poche, and to the Sorbonne where he's taking classes in the midst of intense political discussion and agitation.

The manifs are stimulating. The theatres are warm and welcoming. And stimulating.

We're in the early years of the so-called experimental theatre, when the absurd is playing out in some of the smallest, and poorest, theatres. The poor student is having the most fun in the cramped, on-the-edge, poor theatres. They, perhaps like him, are determined and resilient. And like him, the playwrights of the so-called "theatre of the absurd" who have been welcomed in Paris are mostly from other countries: Ionesco from Romania, Arrabal from Spain, Beckett from Ireland, Adamov from Russia.

Five decades later, in 2010, the former student attended, at the UNESCO headquarters in Paris, the celebration of World Theatre Day, where Augusto Boal was honoured. Boal delivered his acceptance speech in French, then in English, then in Portuguese. I do not speak or understand a word of Portuguese, but found the third version most moving. I thought: "Tiens! I can relate to our spectators, many of who know little French. But they know the situation and themes, and find themselves resonating to the harmonie imitative, the rapprochement of word, tone and gesture to convey ideas, actor embodiment that seems, well... authentic as long as they are comfortable with their script." Am I a raving optimist? I think not. Partly because of what Boal said, simply, memorably and in three languages: "Theatre is life."

Now for Lesson \#1, learned and reinforced at the edge of the stage: Theatre Celebrates the Act of Creative ReEnactment-on so many levels.

In French, a performance is une représentation, a re-presentation of an original experience, but with a new tone and nuances that are determined, not just by the performers but also by the audience. To hear an enthusiastic endorsement of the power, mystery and exhilaration of creative re-enactment, you just have to talk with actors like the three who are here this morning, each of whom has performed in the annual tours which comprise more than twenty school performances, or représentations, for more than three thousand spectators each time, during a two-week period. 
Re-enactment on many levels. First, on a deeply personal level: one day it dawned on me that, as a teacher, I am reenacting discoveries made by that young man, in the streets and theatres of Paris, many years ago.

Re-enactment on the level of story and theme. Together, a Tintamarre cast, like any other, re-enacts, through story and script, an original vision of the world, and of some of the people who inhabit the world.

Re-enactment on the prosodic, lexical and cultural-referent levels. We re-enact discovery of rhythm and language, world views and socio-cultural insights that come together in the magical space of theatre, which is the intersection of a particular place and a particular time.

In the summers, I teach stylistics, not theatre, to very competent American graduate students, and help them to interrogate a culture of consent, to problematize issues, to consider many viewpoints through their writing.

As exhilarating as that is, I look forward to September when I return to Canada, to meet a group of volunteers from throughout the university who have come together to create a play that is collaborative, bilingual, comedic... and activist. My role is to write the script, sometimes with help from students-David said he would like to write a scene for our current production-but that only happens after we have chosen a subject, brainstormed, done dramatic improv, played theatre games, argued and laughed in a safe space where risk-taking is encouraged.

It's impossible to say what is more exhilarating-the creation stage (first semester), when we imagine the fictional space, shape the story that unfolds in that space, and imagine characters who will articulate their differences and resistances in the space; or the production phase (second semester), when we rehearse in the conventional manner, but with special attention to language, prosody and rhythm. The two phases make one think of Baudelaire's two-phase perception of imagination: the spontaneous stage and the constructive phase.

In any event, Lesson \#2 is re-affirmed by this process: both the conceptual and interpretive phases celebrate theatre as an interrogation of our world. Recently, Michel Bouquet, a French actor, declared that "theatre is the only place where the most serious questions can be asked."

Just as we want the rehearsal hall to be a safe space for young actors, so the stage is a safe space where they can, in a playful manner, ask and share serious questions about the world spectators left when they came into the theatre. Theatre is serious play that transports us into a magical and sensual alternate world that makes us forget the pseudorational material world where dialogue is too often monologue, politeness is repressive, and choices are illusory.

In recent years, students have driven Tintamarre's activist agendas, with the result that our little community attracts more students who are looking for a space where articulation of resistances is not just tolerated-it is protected and encouraged. This synergy has conferred on Tintamarre a certain activist cachet.

To cite one example, a student I did not know came to my office in the winter of 2010 to talk about Tintamarre plays he had seen and, as our long conversation was winding down, he said "I have a subject to propose." The result was our 2010-2011 show, Bouffe, a comedy that exposed, in a very playful manner, the fast-food industry. The Mister Bouffe restaurant was succeeded last year by Camp, set in a summer camp where children suffered from eco-phobia, separation from, and fear of, the natural world; and this year's comedy explores alienation from the past.

Needless to say, the activist agendas provide a raison d'être for language study. The director's challenge is to ensure that the script is authentic to avoid fossilization of errors, and to provide textual material that privileges three types of language that can be missing from curricula: words, expressions, and dramatic lines that are practical, picturesque, and poetic. Hence, Lesson \#3:

\section{Theatre Engages a Broad Language Spectrum}

In the beginning was Molière, the great French classic playwright. Production of several Molière scripts allowed us to work with comedy of situation, language and character; to explore human obsession and idées fixes; to better understand comedy as, in the words of Bergson, le mécanique plaqué sur le vivant; and to experience just what makes people laugh.

Over the years we also produced many other plays, from Jarry's iconoclastic and remarkably adaptable Ubu Roi to Roger Vitrac's surrealist flop-turned-smash-hit a generation later when people were ready to consider that our culture sacrifices its children: Victor ou les enfants au pouvoir; from Anouilh's Antigone and L'Alouette, his play about Joan of 
Arc, to Eric-Emmanuel Schmitt (Le Visiteur, the incomparable encounter between Freud and a visitor who turns out to be God); plays from the Québécois repertoire; and, of course, theatre of the absurd.

\section{Lesson \#4: Embrace the Absurd}

Eugène Ionesco, the dean of so-called "theatre of the absurd," did not like the term, arguing that the world is absurd, and that his theatre was a new language to better convey the feeling of being, as Camus' Outsider discovered, in the world but not of the world. A close look at his scripts reveals strategies that have certainly not lost their relevance in the last fifty years:

(i) comedy that emerges from le vivant plaqué sur le mécanique, reversing Molière. Think of his Bald Soprano where, for fleeting instants, the mechanistic Madame Smith flirts with the Fireman who has come to her house in the hope that there might be a fire that he might extinguish, to give his life a purpose;

(ii) unconventional lack of dramatic motivation, as there can be no discernible link between what characters do and why they do it;

(iii) enumerations and proliferations, in a post-war world devoid of values where le chosisme is rampant;

and (iv) dialogue that reflects life as a discontinuous series of immediate experiences. Tweets and status updates, anyone?

When you find the courage to write original scenes and scripts, keep the canon in mind, whatever your canon happens to be. In our case, collaborative scripts are infused with the absurd and, if you will indulge me with a reflection on our style, I would call it absurdo-réalisme.

I hope you have sometimes thought that the absurdist disconnect between Self and the world is a reality that education hides from students. Flirtation with the absurd, in a real-life setting, promises huge rewards for anyone who undertakes second-language theatre with, among other goals, language acquisition in mind. Album, our play which is opening in five days explores our disconnect with the past, and features a large non-nuclear family-in times of economic uncertainty some surprising bedfellows will gather under the same roof (realism)—where only the small children hear voices of ancestors in huge portraits on the wall (absurdism).

Twenty years after Faith Popcorn warned us of cocooning, then burrowing, the teen-aged daughter in our fictional family is, like everyone else, trapped in a silo; hers is her smart-phone, and her virtual community that prevents her from communicating with people directly in front of her.

The Bald Soprano, Ionesco's iconic absurdist play that has now played continuously in one of those cramped, poor Parisian theatres for six decades, was inspired by a language manual, English without Toil. And how many language manuals have conveyed life as a discontinuous series of immediate experiences, where there is a disconnect between what people say and why they say it?

Ionesco's second huge success, La Leçon, features a professor who kills a student because she has a toothache and her own affective reality disrupts her ability to focus on his "Lesson" which is, of course, disconnected, discontinuous, absurd. After the event, he panics and says to the Maid who, in our production like many others, was played by a man: "She was a bad student. What should we do, Mary?" Mary's answer is stern and swift: "We'll put her in the basement, with the thirty-nine others."

\section{Lesson \#5: Self-Parody}

Our second original play, situated in time between plays from the repertoire and the current-day collaborative productions, reflected my own take on teaching as mass-murder. Enter Linguaman!

In Ecoutez, n'écrivez pas, a title borrowed from instructions for oral tests, members of a French class succumb to boredom, one by one, and fall to the floor. When all have expired, the professor panics and flees. Enter the janitorour plays are always anti-hierarchical-who recovers quickly from his shock, rips off his uniform to reveal a blue spandex outfit adorned with a very large " $\mathrm{L}$ ", and sets to work. Linguaman has infiltrated the school under the guise of a janitor, and resuscitates the students, chanting, writhing, and using a magical method-la méthode mimo-gesto-vovotonale pour l'enseignement du français. The grateful students sing a concluding rap: "Linguaman, he's our man, he can find a poubelle in a garbage can!" 
Our subversive piece, presented seventy-six times, told audiences they have to love a language whose alchemical processes transform a garbage-can into a poubelle-pronounced, of course, with a peppy, plosive ' $p$ ' and a languid, lingering, liquid 'l.'

When spectators occasionally recount plays long after the fact, it's interesting to note what they recall, and they make me think of that night many decades ago when I entered a Montparnasse theatre and saw the spectacle of an old couple who take refuge, in a corner of their living-room, from their son who is growing uncontrollably in the next room. Suddenly, in Ionesco's Amédée, a gigantic foot comes crashing through the door. That's what the twenty-year old was certain to remember.

\section{Lesson \#6: Images as Mediation}

We often hear that young people inhabit a world of images. But let's set aside the grandiose images from megamusicals, and the dangerous images from video games that can lead people into the cocoons and burrows that Faith Popcorn told us about. Here we're interested in the images that bridge the language gap and lead us into the world of the play and complement expressive actors who help the spectators make meaning.

Our goal is to share modest, hand-made, homemade, inexpensive images-made from imagination rather than money-which are nevertheless compelling.

Kelley, a fourth-year student whose French is limited, joined Tintamarre in September after having been a spectator for four years. She recounted, on David's radio show, her desire to be on stage because "[The plays] are energetic and visually stunning. You get drawn in" (Tintamatin 2, September 27, 2012). Perhaps spectators will remember Album, long after next week, as the play where ancestors came off the wall. And this image might serve as a mediating image to help people remember why they came off the wall-in this age of short-term memory, we are all susceptible to what Mémère, played by Rosalind, calls "collective amnesia."

You see some of the images behind us this morning, and they also appear on our website: http://www.mta.ca/tintamarre/.

Kelley was followed, on that particular episode of our radio program, by Bernard who explained, with ironic exuberance, that seeing his first Tintamarre show (he was not on stage in his first year either) was both welcoming and infused with wonderment. This was Bus 36, a comedy we created to evoke urban alienation as very diverse people co-habit a bus. Bernard said: "There were a spider-woman and a spark plug. Just like home."

The "spider-woman" was a repressed, rebellious passenger who could not refrain from practicing parkour, even on a bus, but I would like to draw your attention to the spark plug, la bougie, another word that, at least to my ears, sounds more poetic in French. I don't remember who suggested, early in our collaborative process, that spectators might meet the bus parts at the top of the show-le volant, la pile, la bougie and, of course, les phares-the headlights that flirted with Bernard and the other spectators. The atmosphere was, I think, weird and dreamlike, and also revealed a technique we have come to favour.

\section{Lesson \#7: The Actor As Effigy}

Theatre is about emergence, about the story, the plot trajectory and the actor's arc. In second-language theatre, at least when Anglophones and Allophones are speaking French, it can be very useful to have them assume rigid, nonhuman, kinesthetically neutral stances to help them evacuate unmotivated movement and personal tics, just as they coordinate gesture with word and the music of the voice. If gesture and movement are fixed, there are three advantages:

(i) the actor can focus on word and tone-pronunciation and prosody;

ii) the actor gains more confidence;

and iii) the spectator is treated to a comedy of the absurdist type as, just like Madame Smith who flirts with the firefighter, human traits emerge from the effigy.

I said that effigy-acting is rewarding at least where Anglophones speaking French are concerned. A bit of anthropological research, in the early days of Tintamarre, led me to assertions that the so-called French "communicative philosophy" involves close harmonization of gesture with word and tone, whereas Italian or American gesture is more disconnected from the other features of language production, a trait that Francophones would call désincarné. I have 
heard Francophone actors say they find that Anglophone actors indulge in gratuitous movement and gesture. Anecdote? Or reality? One of the most memorable lectures I have ever attended was given by the iconic director, JeanLouis Barrault, at his Théâtre du Rond-point, in Paris, and was entitled "Le Langage du corps." I thought of our actorstudents when Barrault spoke, almost mockingly, of the thousands of contractions inutiles that we execute in the course of a day when we are not on a stage. Hence, my confidence when I tell actors to remain in position and in character, not to suggest they are waiting for a bus.

Eight of the thirty actors in our current production occupy positions in a family portrait, and in two make-believe paintings, on a living-room wall. Their slow, intermittent, and somewhat spastic, emergence from rigidity is suitable to convey listening walls, is a rewarding acting exercise where language is incarné, embodied, and will, we hope, delight audiences next week.

Both David and Bernard played animals_-Ours and Hibou-Bear and Owl, who were omniscient narrators in last year's play, Camp, as they lurked around a summer camp, provoked the eco-phobia of the young campers, and lamented the effects of global warming wrought by humans. They were not mechanical like a bus battery, but inhabitants of a neutral, non-human space where there is no place for our everyday contractions inutiles.

A very memorable non-human character also lurked in our fictional restaurant in Bouffe, our recent play about the fastfood industry. She - it? - was memorable for her appearance, a bright-coloured slinking character who, we decided in our costume-brainstorming session, might look both pre-historic and futuristic. Our university theatre's resident designer - we could not do what we do without her - rose to our challenge, and the resulting primeval metallic character graced the university's website for a full two years.

This character embodied the power of language as well as the power of images, as she was also memorable for her name: Hypersuperalphabétachimipifpafpatatrasvlanboumomégacrash. If you have ever tried to understand incomprehensible terms on food packages, you will recognize this character as a food additive.

This brings us to Lesson \#8:

\section{The Power and Enjoyment of Language Play}

Imagine our pleasure when, in our post-show discussions when Bouffe played in schools, young spectators said, in front of peers, "Would you please say that name again?" And it was fun to deconstruct the name with them, and to explain Hyper! Super!, alpha and béta as the first Greek letters, chimi- of course!, Pif! Paf! Patatras! Vlan! Boum! from cartoons, oméga as the final Greek letter, and crash, an English word Francophones have borrowed, and an ominous ending for a fun word.

And imagine my pleasure when, as I listened to David and Rosalind's radio program, they devoted time to favourite words and expressions: "Alors, mes amis, what are one or two of your favourite French expressions or lines from our current show?"

One of everyone's favourite warm-up activities is to deliver a line they really look forward to saying in the show, in character and with the tone and gesture they have developed. Then, of course, everyone becomes that character and delivers the line. What a rewarding activity, which features empathy, play, and embodied language practice!

Too many students resemble the child of Saint-Denys Garneau's Spectacle de la danse: Mes enfants vous dansez mal / Il faut dire qu'il est difficile de danser ici / Dans ce manque d'air /

Ici sans espace qui est toute la danse. The tragic and misunderstood Québécois poet also celebrates children's (read "our") need for space, as they declare, in another of his poems entitled "Le Jeu" ("Play"): Ne me dérangez pas, je suis profondément occupé. Deeply occupied, refusing to be disturbed in the safe and egalitarian space of the playroom, they play with toys that turn out to be words.

In the second Tintamatin, it was Rosalind who declared, like Saint-Denys Garneau's child: "[When we rehearse], there is no hierarchy." She said that, for our collaborative plays, "We move towards [the script] instead of starting with it." Pierre Bourdieu (L'Inconscient des écoles) would probably have agreed that, in a scholarly milieu, the most formidable hierarchy is that of the script. The actors with whom I work celebrate Bourdieu's need for insubordination, and their joy in rehearsals is a continual reminder of the great contradiction of the academy: a space for questioning conventional wisdom, liberal in its vision, which can be so repressive in practice. 
The child grows, discovers, and experiences wonderment in face of a bewildering world-a process that one lonesco critic called détonnement, becoming un-surprised. So does the artist who, for Saint-Denys Garneau, is "a child who refused to grow up." Any Tintamarre actor will tell you: don't neglect warm-ups, where we aim to encourage the creation of a safe space that is physically engaging. We aim to privilege circles rather than lines or squares, games that are playful and liberating, and a relaxed timeline that will encourage story telling and reflection.

\section{Lesson \#9: Space, Time, and Warmups}

Our warm-up space resembles the community-building venue described by Peter Block: "The context that restores community (and) is one of possibility, generosity, and gifts, rather than one of problem solving, fear, and retribution." Possibility comes with the abandonment of hierarchy, generosity fosters egalitarianism, and gifts solidify the bonds of community.

This space can pre-figure the theatre space where generosity abounds. Actor-students suggest characters that I hasten to enact in a script. One night last semester they suggested the black sheep of the family: I made him an artist. When they suggested a grandfather who lives in the attic, I created Pépère-played by Bernard-who feels excluded from the family narrative, from which he also flees by trekking throughout the house every afternoon, ostensibly to remain in shape. Absurdo-realism, anyone?

In the virtual spaces where our actor-students speak about their experience - the radio program, the blogs, our web site - they talk a lot about our warm-ups, and-music to the ears of the pedagogue-they share their joy of discovering, like Saint-Denys Garneau's child, new words which the dramatic process incites them to use, over and over again, without ever becoming tired-particularly if the words are incarnés—rooted in a meaningful and vital context.

Why can't we invent new words? It has often been said that there are two groups of artists-those who produce the canon and the people who walk in the street. Drama can provide:

(i) a locus for word-creation;

(ii) a safe space, not only for subversive enquiry but also for word-testing;

and (iii) the illusion that, when a character is speaking, the statement is being made for the first time.

This illusion is mediated by the features of expression, which leads us to Lesson \#10: Expression, Not Just Communication.

These days, I am giving a French conversation course with a class of seniors. However, when I wrote the syllabus, I was careful to announce "Conversation and Expression." You should see the joy-yes joy-of these silver-haired children who embody so-called meta-language that we celebrate in all our exercises. They love interpreting Oh, là, là!, Aïe, aïe!, Bof!, Euh..., Zut!, Flûte!, Zut, alors!, Et puis?, words which can appear devoid of cognitive significance and which nevertheless convey attitudes and viewpoints of real people.

Just as Rosalind said that we move towards the script—rather than labouring under its weight—the process of theatrical creation, which is nevertheless focused on an eventual product, so we replicate the emergence of language when we validate expression as well as communication. Exercises feature this emergence, from movement, to gesture, to phoneme, to phonetic words, to rhythmic groups, to enunciation, through accents (tonic and emotive), moving into a dramatic context, which implies motivation, attitude and world-view. Just as directors and actors see scripts as series of beats, so second-language theatre practitioners can see speech acts, motivated by the realization that speech itself is a dramatic activity.

Our tenth lesson has corollaries. Lesson \#11: Theatre Celebrates Silence, an essential feature of expression and communication. It was probably production of scripts by Samuel Beckett, where silence is the "silent player," which confirmed for me, more than any other, the power of theatre to convey the silence of life. The great director, Peter Brook, situated theatre entre les deux silences, the one awkward and the other deep and full of promise.

Any teacher or student—remember they are both "spect-actors"—can resonate to the validity of the two silences, and second-language actors and directors find immense satisfaction in silence as a locus for authentic dialogue, liberation, and power. 
Another corollary of our apology for expression, language as a place we inhabit, is Lesson \#12: Vive les choeurs / Long Live Choruses! Not only is the chorus one of the oldest features of drama and theatre, it promotes empathy and listening, confidence and teamwork, and-there's safety in numbers!

We almost always have choruses, and I sense that actors, and spectators, appreciate this activity, which is no longer a feature of most people's lives. They are also just one of the mirroring activities that have taken their place in our methodology. In Album, our current production, spectators will encounter choruses of inquisitive and repressive neighbours, as well as a chorus of cousins and the characters in the wall portraits.

We have often introduced choruses in productions of works from the repertoire. For example, when I directed Sartre's Huis clos (No Exit), his evocation of Hell which we staged non-stop for an entire night just a few years ago, we created a non-intrusive chorus which spoke in the nine languages spoken by, or known to, cast members. Hell is, after all, reputed to be an inclusive place!

Choruses are an expressive reminder that language-learning need not be the solitary activity it too often becomes, and here is a lesson that has been implicit so far: Lesson \#13: Theatre is a Team Sport. Here, I have only to think about the hundreds of school students who have said, during talk-backs and in the evaluations they write after we have left their school, often as a class exercise: "You looked as if you were having so much fun!" This is often said with envy, or with nostalgia.

The amateur and collaborative theatre process can replicate Scott Peck's formation of community in five stages: "forming, storming, norming, performing and transforming" (The Road Less Travelled). The three actors and I could tell you stories that testify to stage 5: transforming. A theatre process can also create so-called pre-figurative spaces, the embodiment of personal politics and anti-hierarchical views and lifestyles that promise future inspiration, and was championed by Giuseppe Rensi, and later by Wini Breines.

Our scripts and productions always feature 'anti-community,' as characters inhabit cocoons from which they must be liberated. For example, family members in Album each live in their own solitude, and a prime example is Victoria-the ironic cultural referent is not accidental-whose smart phone links her to a vast community which, however, cuts her off from the ancestors on the wall, even the other family members who crisscross the living-room, a salon which, according to Pierre, the youngest child who, by his own admission, is gifted: is not a salon, but a salle des pas perdus.

Here we come to Lesson \#14: Power to the Children! the title of Roger Vitrac's surrealist bomb. We often create characters who are child-like, not childish, who can remind Jungians of the puer aeternus, or eternal child who inhabits us all, not like the Freudian child who must be excised, killed, to ensure the psychiatric health of the adult. French theatre is littered with dead children, and child-sacrifice is symptomatic of a sick culture, is it not?

So we take our inspiration from the Antigones, from the Victors, and from the child who inhabits the poetry of Jacques Prévert:

Tu dis que tu aimes la pluie, et tu fermes la fenêtre,

Tu dis que tu aimes les fleurs, et tu leur coupes la queue,

Tu dis que tu aimes les poissons, et tu les pêches, et tu les manges.

Alors, quand tu me dis que tu m'aimes,

J'ai un peu peur!

We also create old characters and they, along with children, display intergenerational conflict, and also mediate reconciliation. The story line of Album involves a rapprochement of a teen-aged daughter and her grandmother, who brought huge portraits of ancestors when she moved in with her daughter. The highlight of a recent rehearsal was a brief but very tense scene between the Mother and her daughter when the actor playing the teenager displayed a magical blend of love and resentment.

Tu dis que tu aimes la pluie... The process of theatre takes us through warm-ups, creation of a safe space, collaborative story telling, and creation of a theatre space, through which people from the story begin to move. 
For our current storyboard, we created, for example, a daughter who, unlike her siblings, is obsessed with our alienation from the past. At one point, she recites Rimbaud's inimitable anti-war poem, Le Dormeur du val, unaware that the Angel and Dying Soldier who inhabit a huge wall painting behind her, are also reciting the poem. Poems are her link with the past and times of war.

\section{Lesson \#15: Theatre and the Return to Culture}

When Jeanne recites Rimbaud-who was younger than our actor when he conceived Le Dormeur du val-her character frames a magnificent cultural referent, just as the simple but imposing structure behind her frames a dramatic moment on the battlefield when death is imminent. The actor speaks in language that is conative rather than phatic (Jakobson), and channels with confidence the détonnement-the journey from innocence to experience-of the young genius who discovered a dead soldier in a ditch, in north-east France, in 1870.

When David, Rosalind, Bernard and others updated radio listeners on the evolution of our current story, their enthusiasm and conviction reminded me of Muriel Gold's route to drama therapy: "the fictional family." For our actors, the eighteen members of the huge 'non-nuclear' family at 7, Chemin du souvenir, are real.

David said on the radio, on October $4^{\text {th }}$, "It's really neat to see some of the characters we suggested or created come alive on the storyboard." It is hence not surprising that one of the most popular warm-up activities in January has been the dramatic improv, in both languages, where two family members meet by chance in a neutral place. One could not overestimate the creativity, the ownership_and the laughter-that exude from the rehearsal space during this activity.

For years I have done whatever I can to provide a sense of continuity in language classes-course mottos, class-team names, and the like. In our theatre process, I now create a storyboard, complete in both languages, first a sketch and later a detailed plot. The detailed storyboard emerges from the group's story, and becomes their play. Telling our Stories (Lesson \#15), and creating a story-whether it be the "arc" of the character within the story of the play, or the unfolding life-story of the actor who moves on the stage_creates at least an illusion of continuity as it makes meaning: deep meaning which can be absent in a second-language classroom if the syllabus and course narrative reflect the discontinuous series of immediate experiences that can overtake us all in the world outside. In this scholarly world, the teacher or director can become an adversary rather than an ally. Alienation is pervasive, yet communities abound. Is it any wonder that, in French, one letter separates soliTaire from soliDaire?

Merci! Thank you!

\section{Notes}

${ }^{1}$ http://tintamatin.bandcamp.com/album/tintamatin-season-one

${ }^{2}$ http://www.podcasts.com/tintamatin 